\title{
Teaching Video NeuroImages: Vestibulo-ocular reflex defect in cerebellar stroke
}

Jens Witsch, MD, Monica Ferrer, BS, and Dhasakumar Navaratnam, MD, PhD

Neurology ${ }^{\circledR}$ 2018;91:e888-e889. doi:10.1212/WNL.0000000000006087
Correspondence

Dr. Witsch

jensjulianwitsch@gmail.com

Figure Brain MRI

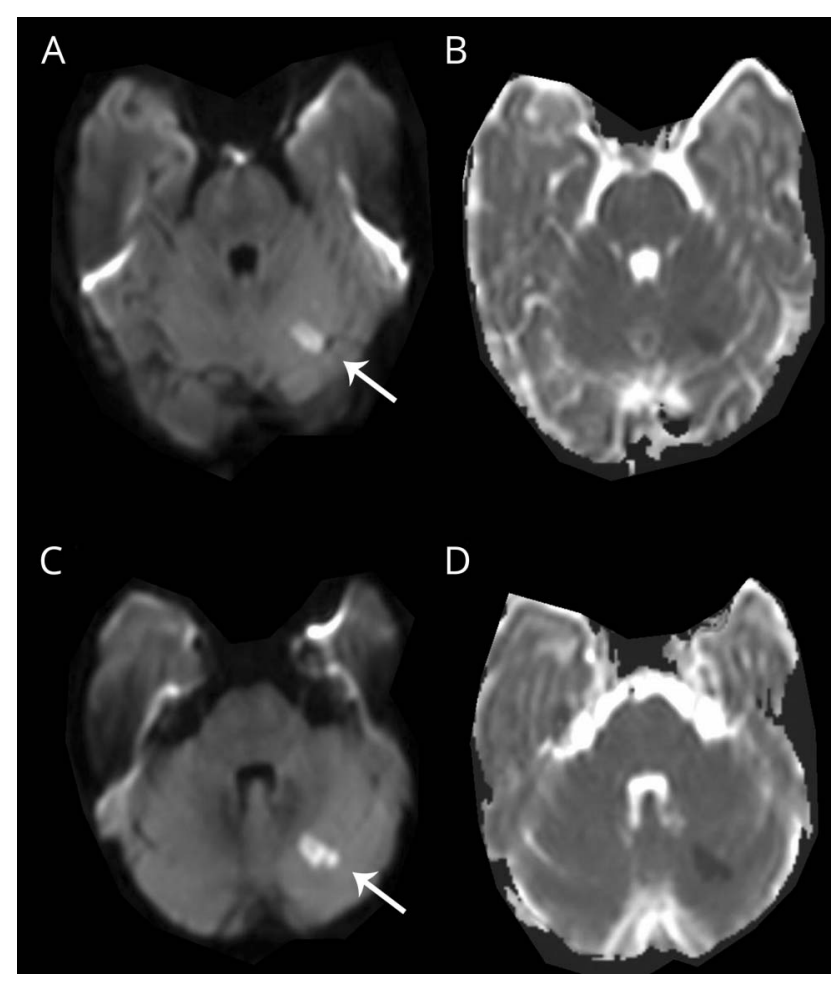

(A) Left cerebellar lesion, hyperintense on the diffusion-weighted imaging sequence (arrows in A and C). (B) Hypointense apparent diffusion coefficient sequence correlate of lesion shown in A. (C, D) Caudal extension of the lesion shown in A and B (thickness of cuts $5 \mathrm{~mm}$ ).

A 69-year-old man presented with acute vertigo, nausea, and vomiting. The patient had leftbeating nystagmus and an abnormal vestibulo-ocular reflex with corrective saccades on right head impulse (video 1). He had impaired pursuits to the left but no other cerebellar/neurologic findings (skew/hearing loss). MRI showed an acute stroke affecting the left cerebellar flocculonodular region (figure). Prior research has shown that an abnormal head impulse test (HIT) strongly predicts a peripheral process, and is inversely associated with posterior fossa stroke. ${ }^{1}$ Our case illustrates the limited specificity of this clinical test. Nine percent of patients with a positive HIT have cerebellar strokes. ${ }^{2}$

\section{Author contributions}

Jens Witsch: clinical care of the patient, study concept, acquisition of data, revision of the manuscript for intellectual content. Monica Ferrer: acquisition of data, drafting of the manuscript. Dhasakumar Navaratnam: clinical care of the patient, study concept, acquisition of data, revision of the manuscript for intellectual content.

\section{MORE ONLINE}

○ Video

$\rightarrow$ Teaching slides

links.lww.com/WNL/

A643 


\section{Study funding}

No targeted funding reported.

\section{Disclosure}

The authors report no disclosures relevant to the manuscript. Go to Neurology.org/N for full disclosures.

\section{References}

1. Kattah JC, Talkad AV, Wang DZ, Hsieh YH, Newman-Toker DE. HINTS to diagnose stroke in the acute vestibular syndrome: three-step bedside oculomotor examination more sensitive than early MRI diffusion-weighted imaging. Stroke 2009;40: 3504-3510.

2. Newman-Toker DE, Kattah JC, Alvernia JE, Wang DZ. Normal head impulse test differentiates acute cerebellar strokes from vestibular neuritis. Neurology 2008;70: $2378-2385$. 


\section{Neurology}

\section{Teaching Video NeuroImages: Vestibulo-ocular reflex defect in cerebellar stroke Jens Witsch, Monica Ferrer and Dhasakumar Navaratnam \\ Neurology 2018;91;e888-e889 \\ DOI 10.1212/WNL.0000000000006087}

This information is current as of August 27, 2018

\section{Updated Information \& Services}

References

Citations

Subspecialty Collections

Permissions \& Licensing

Reprints including high resolution figures, can be found at: http://n.neurology.org/content/91/9/e888.full

This article cites 2 articles, 2 of which you can access for free at: http://n.neurology.org/content/91/9/e888.full\#ref-list-1

This article has been cited by 4 HighWire-hosted articles: http://n.neurology.org/content/91/9/e888.full\#\#otherarticles

This article, along with others on similar topics, appears in the following collection(s):

\section{All Cerebrovascular disease/Stroke}

http://n.neurology.org/cgi/collection/all_cerebrovascular_disease_strok e

\section{All Clinical Neurology}

http://n.neurology.org/cgi/collection/all_clinical_neurology

Clinical neurology examination

http://n.neurology.org/cgi/collection/clinical_neurology_examination

Nystagmus

http://n.neurology.org/cgi/collection/nystagmus

Ocular motility

http://n.neurology.org/cgi/collection/ocular_motility

Information about reproducing this article in parts (figures,tables) or in its entirety can be found online at:

http://www.neurology.org/about/about_the_journal\#permissions

Information about ordering reprints can be found online:

http://n.neurology.org/subscribers/advertise

Neurology ${ }^{\circledR}$ is the official journal of the American Academy of Neurology. Published continuously since 1951, it is now a weekly with 48 issues per year. Copyright (O) 2018 American Academy of Neurology. All rights reserved. Print ISSN: 0028-3878. Online ISSN: 1526-632X.

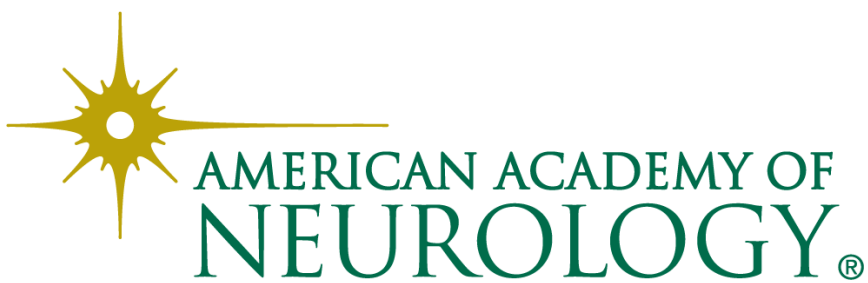

